\begin{tabular}{|c|c|c|}
\hline Beitr. Ent. & Berlin & ISSN 0005-805X \\
\hline $49(1999) 1$ & S. $107-131$ & 6.04 .1999 \\
\hline
\end{tabular}

\title{
The diving beetles of Kamchatka, with additional records from Sakhalin and the Kuril Islands
}

\author{
(Coleoptera: Dytiscidae)
}

\author{
ANDERS N. NILSSON, SERGEY K. KHOLIN \& NOBORU MINAKAWA
}

\begin{abstract}
Summary
The dytiscid fauna of the north-east Asian peninsula Kamchatka is reviewed based on literature records and more recent collections. The following ten species are here reported from Kamchatka for the first time: Hygrotus marklini (GYLlenHAL), Hydroporus notabilis LeCONTE, H. submuticus THOMSON, H. tristis (PAYKULL), H. uenoi NAKANe, Oreodytes okulovi LAFER, Agabus balkei FERY \& Nilsson, A. discolor HARRIS, Ilybius chishimanus KôNO, Rhantus suturellus (HARRIs), and Graphoderus perplexus SHARP. Altogether 38 species of Dytiscidae are now known from Kamchatka, and of these 22 have Holarctic distributions. Graphoderus perplexus is here reported for the Palearctic Region for the first time. Additional records are given for Sakhalin and the Kuril Islands. The following four species are here reported from Sakhalin for the first time: Hydroporus nigellus MANNERHEIM, Agabus kholini NILSSON, Ilybius angustior (GYLlenHAL), and Acilius canaliculatus (NicOLAI). The following ten species are here reported from the Kuril Islands for the first time: Hydroporus nigellus, H. notabilis, H. submuticus, H. tristis, Agabus clypealis (THOMSON), A. confinis (GYLLENHAL), A. costulatus (MOTSCHULSKY), A. discolor, Ilybius discedens SHARP, and Colymbetes dahuricus AUBÉ. Nine of the species were found in the North Kurils, whereas H. tristis was found in the South Kurils. With these additions, 39 species are now known from Sakhalin, and 36 from the Kuril Islands.
\end{abstract}

\section{Zusammenfassung}

Die Dytiscidenfauna der nordostasiatischen Halbinsel Kamtschatka wird auf der Grundlage von Literaturnachweisen und neueren Aufsammlungen zusammengestellt. Die folgenden zehn Arten werden erstmals für Kamtschatka nachgewiesen: Hygrotus marklini (GYLLENHAL), Hydroporus notabilis LECONTE, $H$. submuticus THOMSON, H. tristis (PAYKUIL), H. uenoi NAKANE, Oreodytes okulovi LAFER, Agabus balkei FERY \& NLSSON, A. discolor HARRIs, Ilybius chishimanus KÔNO, Rhantus suturellus (HARRIs), und Graphoderus perplexus SHARP. Insgesamt 38 Dytiscidenarten, davon 22 mit holarktischer Verbreitung, sind nun von Kamtschatka bekannt. Graphoderus perplexus wird erstmals aus der Paläarktis nachgewiesen. Weitere Nachweise werden für Sachalin und die Kurilen genannt. Die folgenden Arten sind Erstnachweise für Sachalin: Hydroporus nigellus MANNERHEIM, Agabus kholini NILSSON, Ilybius angustior (GXLLENHAL), und Acilius canaliculatus (NICOLAI). Zehn Arten werden erstmals für die Kurilen nachgewiesen: Hydroporus nigellus, H. notabilis, H. submuticus, H. tristis, Agabus clypealis (THOMSON), A. confinis (GYLLENHAL), A. costulatus (MOTSCHULSKY), A. discolor, Ilybius discedens SHARP, und Colymbetes dahuricus AUBÉ. Neun dieser Arten wurden auf den nördlichen, H. tristis dagegen auf den südlichen Kurilen gefunden. Damit sind jetzt von Sachalin 39 und von den Kurilen 36 Arten bekannt. 


\section{Acknowledgements}

We thank Pascal LEBLANC for help in finding the holotype of Hydroporus penitus.

The work described here was supported in part by the International Programs Division and the Biological Sciences Directorate (Biotic Surveys and Inventories Program) of the U.S. National Science Foundation, Grant Nos. DEB-9400821 and DEB-9505031, Theodore W. PIETSCH, principal investigator, and by the Japan Society for the Promotion of Science, Grant No. BSAR-401, Kunio AMAOKA, principal investigator. S.K. KHOLnN's visit in Kamchatka and the North Kurils during the Joint Japanese-Russian Expedition was supported by the Chiba Prefecture's Government and the Natural History Museum and Institute, Chiba. We thank Dr. G. LAFER, Vladivostok, and Dr. Yu. MARUSIK, Magadan, for providing important information.

\section{Introduction}

Kamchatka is the largest peninsula of north-east Asia. It covers a total area of about $370,000 \mathrm{~km}^{2}$. In the north part, Kamchatka is connected with the continent by a narrow isthmus $\left(-60^{\circ} \mathrm{N}\right.$, the so called Parapolsky Dol, about $100 \mathrm{~km}$ wide), and extended for about $1,200 \mathrm{~km}$ from NNE to SSW $\left(\sim 51^{\circ} \mathrm{N}, 156^{\circ} 40^{\prime} \mathrm{E}\right.$, Cape Lopatka). The south part of the peninsula is separated from the Shumshu Island (the northernmost island of the Kuriles) by the $12 \mathrm{~km}$ wide First Kurile Channel.

Kamchatka is characterized by its mountainous topography [about $3 / 4$ of the peninsula is covered by mountain ridges that reaches elevations of 3000 to $3500 \mathrm{~m}$ a.s.1. (maximum $4750 \mathrm{~m}$ )] and the volcanic activity from the Palaeozoic up to the present time (much more intensively in past). Along the west coast is the Zapadnaya (West) Plain situated with its extensive marshlands. Small areas of lowlands with peatbogs are found on the east coast at the outlets of the rivers. In the central part of the peninsula occurs the intermontane Central-Kamchatka depression (extending from $53^{\circ} 10^{\prime} \mathrm{N}$ nearly to the coast of the Bering Sea) with the largest river of the peninsula (Kamchatka River).

The pronounced latitudinal extension, atmospheric phenomenons, varied topography, and the different temperature regimes of the surrounding seas create a variety of climatic conditions in Kamchatka. Generally, the west coast has a colder (and relative dry) climate than the east coast. Both coasts are under the influence of the monsoon circulation in the atmosphere. The central part of the peninsula has a sharply different climate relative to the coasts. It may be defined as continental (much warmer summer and colder winter).

Kamchatka has a very rich system of permanent rivers, small streams with very clear water from melting ice and snow on the mountains, lakes and hot springs. Large areas on the plains are covered by Carex-Sphagnum and Carex-Lichen bogs. The lakes in Kamchatka differ in their origin, i.e. affected by volcanic, tectonic, maritime, glaciation or other activities.

The flora and fauna of Kamchatka show many insular characteristics. The composition and distribution of the forest vegetation is affected by climatic patterns, volcanic activity and diversified landscape. Generally, this area comprises boreal vegetation. Betula ermanii CHAM. forms a park-like forest below $500 \mathrm{~m}$ a.s.l. with tall and subalpine herbs, or with subalpine krummholz (Pinus pumila (PALL.) RGL. and Alnus kamchatica (CALL.) KOM.). The forests are dominated on central Kamchatka by larch (Larix dahurica TURCZ.), spruce (Picea ajanensis FISCH.) and birch (Betula platyphylla SUKACS. and B. ermanii) and are distributed up to $1000 \mathrm{~m}$ a.s.l. The forest zone is spread toward the north at $58^{\circ} \mathrm{N}$. The northernmost part of Kamchatka and a narrow belt along the west seashore is treeless moss and lichen tundra.

The following list is based on a combination of literature records and the examination of the specimens collected by S. K. KHOLIN in Kamchatka in 1997. The given additions to our earlier works on Sakhalin and the Kuril Islands (NILSSON \& KHOLN 1994, NILSSON et al. 1997) are based on the results of the 1996 and 1997 American-Japanese-Russian Kuril Expeditions plus S.K. KHOLIN's and YU. MARUSIK's 1995 and 1997 separate visits to these islands. This material is 
deposited chiefly in the Fish Collection, University of Washington, Seattle, and the locality data are given below. Additional specimens were studied in the collections of a few museums. The list includes all species of Dytiscidae so far recorded from Kamchatka. For each species are listed the synonyms of special interest with references to all literature records from Kamchatka. Geographical distributions are outlined giving preference to the adjacent regions of NE Asia of which the dytiscid fauna has been revised, i.e. Primorye, Sakhalin, Hokkaido, and the Kurils.

\section{Coding of localities}

The Kamchatka localities visited by S. K. KHOLIN in 1997 are coded as:

(1) Ganalskaya Tundra, artificial lakes with sparse marginal vegetation and sand-stone bottom, 30.vii;

(2) dito, small residual pool with sand-stone bottom without any vegetation, 30.vii;

(3) dito, temporary ponds with moss, 30 .vii;

(4) Nagorny, $6 \mathrm{~km}$ NW of Petropavlovsk-Kamchatskyi, peat bog pool, 10.vii;

(5) $18 \mathrm{~km}$ S Elizovo, Bystraya River, residual pool in broadleaved forest 10.vii;

(6) $12 \mathrm{~km}$ S Elizovo, Tikhaya River, ponds with moss in bog, 9.vii;

(7) $17 \mathrm{~km} \mathrm{NE}$ of Malki, middle reaches of Poperechnaya River, spring pool with moss, 28.vii;

(8) Foothills of volcanoes Vochkazchty, ponds, 2.viii;

(9) dito, lake and pools with spring water and moss, 1 .viii.

Localities from the 1996 and 1997 American-Japanese-Russian Kuril Expeditions are coded as the two-letter island code plus the original sample number. Note that more detailed information on these samples can be recieved from the authors; in this case the original sample codes should be referred to, i.e. two-character island code, two-digits year code, 2-3 character collector code, plus the sample number, e.g. IT-96-NM-10. These codes can be extracted from the information given below:

Iturup (IT): (6C) $4 \mathrm{~km} \mathrm{E}$ of Kitovyi, roadside puddle, 29.vii.97; (7) $4 \mathrm{~km} \mathrm{E}$ of Kitovyi, roadside puddle, 29.vii.97; (8) dito; (10) dito; (29) Dobroye Lake, shore \& bogs, 23.viii.96; (72) Dobroye Nachalo Bay, shallow pond, 22.viii. 96.

Kharimkotan (KH): (33) $2 \mathrm{~km}$ inland Severgina Bay, pond, 8.viii.96; (35) $3 \mathrm{~km}$ inland Severgina Bay, pond, 8.viii.96; (42) $0.2 \mathrm{~km}$ inland Severgina Bay, small pond, 8.viii. 96 .

Kunashir (KU): (40) 17km W Yuzhno-Kurilsk, geothermal pool, 25.viii.96; (77) Aliger Lake, surrounding ponds, 26.viii.96.

Matua (MA): (56) 0.5km inland Aynu Bay, lake, 14 viii. 96.

Makanrushi (MK): (70) inland of Zakat Bay, Spagnum in meadow depression, 18.viii.97; (76) $0.5 \mathrm{~km}$ inland of Zakat Bay, pond, 18. viii.97; (79) $2 \mathrm{~km}$ inland of Zakat Bay, pond, 18.viii.97; (81) $0.1 \mathrm{~km}$ inland of Zakat Bay, pond, 18.viii. 97.

Onekotan (ON): (14) $2 \mathrm{~km}$ inland Nyemo Bay, small pond, 4.viii.96; (15) $2.5 \mathrm{~km}$ inland Nyemo Bay, 2 small ponds, 4.viii.1996; (16) $2.5 \mathrm{~km}$ inland Nyemo Bay, 2 small ponds, 4.viii.96; (17) $4 \mathrm{~km}$ inland Nyemo Bay, large pond, 4.viii.96; (18) 4.2km inland Nyemo Bay, ponds, 4.viii.96; (26) $4 \mathrm{~km}$ inland Mussel Bay, $\mathrm{N}$ of Resvyi River, stream, 7.viii.96; (28) 4km inland Mussel Bay, N of Resvyi River, pond, 7.viii.96; (29) 4km inland Mussel Bay, $\mathrm{N}$ of Resvyi River, ponds, 7.viii.96.

Paramushir (PA): (2) $0.2 \mathrm{~km} \mathrm{~N}$ of Utyosnaya River, small pond, 1. viii. $96 ;$; (4) $0.2 \mathrm{~km} \mathrm{~N}$ of Utyosnaya River, small pond, 1.viii.96; (6) $0.1 \mathrm{~km}$ N Utyosnaya River, large pond, 1.viii.96; (8) Utyosnaya River, 1.viii.96; (9NM) Vasiljeva Peninsula, small pond, 3.viii 96;(9PO) Vasiljeva Peninsula, large pond, 3.viii.96; (10) dito; (11) Vasiljeva Peninsula, 2 small ponds, 3.viii.96; (23) NE corner of island, Putyatino, pond, 4.viii.97; (24) inland Severo-Kurilsk nr Kuzminka River, bog, 5.viii.97; (35) Severyanka River valley, small ponds, 11.viii.97; (36) $0.2 \mathrm{~km}$ inland Cape Ozernyi, bog pools, 11.viii.97; (42) Vasilyeva Peninsula, small fish pond, 16.viii.97; (45) Vasilyeva Peninsula, small pools, 16.viii.97; (48) inland $W$ base of Vasilyeva Peninsula, small pond, 16.viii.97; (52) inland Cape Krepkii nr Utyosnaya River, ponds, 11.viii.97; (60) inland Krasheninnikova Bay nr K. River, meadow puddle, 14.viii.97; (64) inland Krasheninnikova Bay nr K. River, pond, 14 .viii. $97 ;(65)$ dito; (67) $0.2 \mathrm{~km}$ inland of Cape Kapustnyi, pond, $15 . v i i i .97 ;(69) 0.3 \mathrm{~km}$ inland W base 
of Vasilyeva Peninsula, 3 ponds, $16 . v$ iii. 97 ; (70) $0.3 \mathrm{~km}$ inland $\mathrm{W}$ base of Vasilyeva Peninsula, pond, 16.viii.97; (71) $0.2 \mathrm{~km}$ inland $W$ base of Vasilyeva Peninsula, pond, 16.viii. 97 .

Shiashkotan (SA): (12) $1.5 \mathrm{~km}$ inland Zakatnaya Bay, pond, 12.viii.96; (13) N slope of Mt. Kuntomintar, stream, 12. viii.96; (15) $0.5 \mathrm{~km}$ inland Zakatnaya Bay, pond, 11.viii.96; (47) Zakatnaya Bay, stream with waterfall, 11.viii.1996; (49) Zakatnaya Bay, small pond, 11.viii.96; (51) $1 \mathrm{~km}$ inland Zakatnaya Bay, 3 large ponds, 11.viii.96.

Shumshu (SU): (29) $2 \mathrm{~km}$ S of Pochtareva Cape, bog pond, 8. viii.97; (30) NE of Cape Chibuynyi nr Ozernaya River, bog pool, 9. viii.97; (31NM) $2 \mathrm{~km} \mathrm{~S}$ of Pochtareva Cape, small pond, 8.viii.97; (31TIR) NE of Cape Chibuynyi nr Ozernaya River, mud pools, 9.viii.97; (34) inland Babushkina Bay nr Juzhanka River, bog pools, 10. viii.97;(41) NE of Cape Chibuynyi nr Ozernaya River, pond, 9. viii.97; (45) inland Babushkina Bay, puddle nr stream, 10.viii.97;(47) $1 \mathrm{~km}$ inland Babushkina Bay, lake, 10.viii.97; (48) 1.6km inland Babushkina Bay, puddle, 10 .viii.97.

Urup (UR): (67) 3km inland Tetyaeva Bay, marsh ponds, 21.viii.96

\section{Collectors:}

CRAWFORD, R.L.: MK-70. - CRAWFORD, R.L. \& SCHWEIKERT, J.S.: TT-6C. - MINAKAWA, N.: IT-7, 8, 10, MK-76, 79, 81, ON-26, PA-9NM, 23, 24, 52, 60, 64, 65, 67, 69, 70, SA-12, 13, 15NM, SU-29, 31NM, 41, 45, 47, 48. - MinAKAWA, N. \& OBERG, P.: IT-29, 72, KH-33, 35, KU-40, 77, ON-14, 15, 16, 17, 18, 28, 29 , PA-2, 4, 6, 8, SA-47, 49. - OBERG, P.: MA-56, PA-9PO, 10, 11, SA-15PO, 51 - OBERG, P. \& LOPEZ, A.: KH42. - PIETSCH, T.W., AMAOKA, K. \& STEVENSON, D.E.: PA-42. - RITCHIE, T.I.: IT-7, 8, PA-36, 48, SU-30, 31TTR, 34. - SAYENKo, E.M.: PA-35. - STEVENSON, D.E.: PA-45.

The Kuril localities visited by S.K. KHOLIN in 1997 are coded as below, and in the list they are separated from the others by the addition of *:

Paramushir (PA): (1) Severo-Kurilsk, Ozernyi Cape, lakes, 13.vii; (2) ibid, middle reaches of Matroskaya River, pools with slowly running cold water, 12 .vii; (3) ibid, various ponds with clear and cold water, 11.vii; (4) ibid, Utesnaya Bay, bog ponds with moss, 13.vii; (5) ibid, outlet of Matroskaya River, ponds with cold water, 12.vii; (6) S of Severo-Kurilsk, lake on the plateau, small bog pools, 24.vii; (7) $3 \mathrm{~km} \mathrm{~N}$ of SeveroKurilsk, lake on plateau, 24.vii; (8) Shelekhova Bay, sedge fen with spring-water, 19.vii; (9) ibid, sedge fen, 16-18.vii; (10) Valley of Shimoyur River, lake with volcanic dross bottom, 17.vii; (11) Outlet of Shimoyur River, pond with volcanic dross and stones and moss, 17.vii. - Shumshu (SU): (1) Bolshoye Lake, small lakes, in moss, 22.vii; (2) ibid, small meadow pond with moss, 21.vii.

The Sakhalin (SK) localities visited by S.K. KHOLIN in 1995 are coded as follows:

South Sakhalin: (1) Pugachevo, 22.ix, man-made ponds in coniferous forest. - North Sakhalin (Okha district): (2) Moskalvo 16-17.ix, small lake; (3) Beregovye Langry, 18.ix, small pond; (4) Beregovye Langry, 19.ix, lake; (5) Beregovye Langry, 19.ix, bog; (6) Beregovye Langry, 19.ix, coastal pond; (7) Beregovye Langry, $20 . \mathrm{ix}$, pond; (8) Beregovye Langry, 20.ix, river mouth; (9) Novye Langry, 20.ix, man-made pond in coniferous forest; (10) Novye Langry, 20.ix, temporary pond.

Museum abbreviations:

(IBV) Institute of Biology and Soil Sciences, Vladivostok, (MZH) Zoological Museum, Helsinki, (NRM) Naturhistoriska riksmuseet, Stockholm, (USNM) National Museum of Natural History, Smithsonian Institution, Washington DC, (ZSM) Zoologische Staatssammlung, München.

\section{The species known from Kamchatka}

For each collecting record is given the code of the sample followed by no. of adults/no. of larvae.

\section{Subfamily Hydroporinae}

\section{Hygrotus impressopunectatus (SCHALLER)}

Dytiscus impressopunctatus SCHALLER, 1783:312 (orig. descr.).

Coelambus impressopunctatus (SCHALLER, 1783): LAFER 1989:236 (key).

Hygrotus impressopunctatus (SCHALLER, 1783): NILSSON \& HOLMEN 1995:36 (descr.). 
New records: $2(1), 4(7), 6(2), 8(7)$.

A widespread Holarctic species known also from Primorye, Sakhalin, the South Kurils and Hokkaido.

\section{Hygrotus inaequalis (FABRICIUS)}

Dytiscus inaequalis FABRICIUS, 1777:239 (orig. descr.).

Hygrotus inaequalis (FABRICIUS, 1777): ZASYPKINA et al. 1996:20 (Kamchatka River).

A widespread Palearctic species that occurs also in Primorye, Sakhalin and Hokkaido. We have not been able to verify the ZASYPKINA et al. (1996) record from Kamchatka. It is most likely correct.

\section{Hygrotus marklini (GYLLENHAL, 1813)}

Hyphydrus marklini GrLLENHAL, 1813:689 (orig. descr.).

Coelambus canadensis FALL, 1919:11 (orig, descr.)

Hygrotus marklini (GYLLENHAL, 1813): NILSSON \& HOLMEN 1995:36 (descr., syn.).

New record: 2(8).

This Holarctic species is transcontinental in North America where it occurs from Alaska to Newfoundland and south along the Rocky Mountains to New Mexico. The Palearctic range extends from Fennoscandia to Mongolia, northern China and the Magadan region. Our record is the first one from Kamchatka.

\section{Hydroporus bergmani NILSSON}

Hydroporus bergmani NLssoN, 1995:23 (orig. descr., Bolscherjetsk).

Hydroporus brevis F. SAHLBERG, 1834: ZIMMERMANN 1931:142 (in part, misident.); ZarTzEV 1953:168 (in part, misident., Kamchatka); LAFER 1989:240 (in part, misident.); ZASYPKINA et al. 1996:20 (misident., Kamchatka River).

This species is so far known only from the type series, collected at Bolscherjetsk by WUORENTAUS in 1917. Literature records of $H$. brevis from Kamchatka and Magadan (ZAITZEV 1953, LAFER 1989, ZASYPKINA et al. 1996) may represent $H$. bergmani.

\section{Hydroporus fuscipennis SCHAUM}

Hydroporus puberulus MANNERHEIM, 1853:163 (orig. descr.); preocc. by LECONTE, 1850.

Hydroporus fuscipennis SCHAUM in SCHAUM \& KIESENWETTER, 1868:64 (replacement name for Hydroporus puberulus MANNERHEIM, 1853, nec LECONTE, 1850); ZIMMERMANN 1925:2, 1931:137 (Kamchatka); NILSSON \& LARSON 1984:123 (syn.).

Hydroporus criniticoxis LARSON, 1975:301 (orig. descr.).

New records: 2(14), 3(9), 5(6), 8(6).

A Holarctic species that is transcontinental in North America. The Palearctic range extends from Germany, Austria and Fennoscandia via northern Russia to Kamchatka, Primorye, Sakhalin and Hokkaido.

\section{Hydroporus laticollis ZIMMERMANN}

Hydroporus laticollis ZIMMERMANN, 1922:20 (orig. descr.); 1931:123 (Kamchatka); ZATTZEV 1953:173 (Kamchatka); LAFER 1989:240 (key, Kamchatka). 
This species was described from Bolscherjetsk in Kamchatka, where it was collected in 1917 by Y. WUORENTAUS. It has later been found also in Sakhalin and Primorye.

\section{[Hydroporus memnonius NICOLAI]}

Hydroporus memnonius NICOLAI, 1822: JAKOBSON 1908:426, ZArTZEV 1953:172 (misident., Kamchatka).

We have not been able to verify JAKOBSON's (1908) record of this species from Kamchatka. As this is a West Palearctic species, it is probably based on a misidentification.

\section{Hydroporus morio AUBÉ}

Hydroporus morio AUBÉ, 1838a:307 + pl. 36:1 (orig. descr.); NILSSON \& NAKANE 1993:421 (syn.); NILSSON 1994a:95 (syn.).

Hydroporus lugubris MOTSCHULSKY, 1845:353 (orig. descr., Kamchatka); preoccupied by AUBÉ, 1838.

Hydroporus caminarius MOTSCHULSKY, 1860:100 (orig. descr., Kamchatka).

Hydroporus melancholicus MotschULSKY, 1860:100 (replacement name for Hydroporus lugubris MoTSCHULSKY, 1845, nec AUBÉ, 1838); JAKOBSON 1908:425 (Kamchatka).

Hydroporus watanabei TAKIZAWA, 1933:174 (orig. descr.).

Hydroporus melanocephalus (MARSHAM, 1802): ZMMMERMANN 1931:119 (misident., Kamchatka); ZASYPKNA et al. 1996:20 (misident., Kamchatka).

New record: $9(5)$.

The world distribution is northern circumboreal and it is known also from Primorye, Magadan, Sakhalin, Hokkaido and the Kurils.

\section{Hydroporus nigellus MANNERHEIM}

Hydroporus nigellus MANNERHEM, 1853:163 (orig. descr.); NILSSON 1994a:93 (Kamchatka).

Hydrocoptus obscuripes MOTSCHULSKY, 1860:100 (orig. descr.)

Hydroporus pyrenaeus WEHNCKE, 1871:163 (orig. descr.)

Hydroporus sieversi J. SAHLBERG, 1910:173 (orig. descr.)

Hydroporus tartaricus LECONTE, 1850:ZMMERMANN 1925:3, 1931:120 (misident., Kamchatka); ZASYPKINA et al. 1996:21 (misident., Kamchatka River).

New records: 2(36), 3(18), 4(9), 5(1), 7(1), 8(39), 9(20).

A Holarctic species that is know also from Sakhalin and the North Kurils (see below). It is seemingly very common in Kamchatka.

\section{Hydroporus notabilis LE CONTE}

Hydroporus notabilis LECONTE, 1850:216 (orig. descr.); ANGUS 1985:274 (syn.).

Hydroporus arcticus THOMsON, 1856:197 (orig. descr.)

Hydroporus tomentosus Poppius, 1905:12 (orig. descr.)

New record: 6(7).

A Holarctic species that is transcontinental in North America. The Palearctic range extends from Fennoscandia to Kamchatka and the North Kurils in arctic and boreal zones. ANGUS (1985) synonymized both $H$. arcticus THOMSON and $H$. tomentosus Poppius with the Nearctic $H$. notabilis LECONTE, and recognized all three forms as subspecies. Our record is appearingly the first one from Kamchatka. 


\section{Hydroporus submuticus THOMSON}

Hydroporus submuticus THOMSON, 1874:537 (orig. descr.); NLSSON \& NAKANE 1993:421 (syn.).

Hydroporus penitus GUIGNOT, 1945:20 (orig. descr.); syn. nov.

Hydroporus konoi NAKANE, 1963:25 (orig. descr.).

New record: 6(2).

This northern Palearctic species is known also from Primorye, Sakhalin, Hokkaido, and the North Kurils. The examination of the holotype of Hydroporus penitus GUIGNOT, described from the Khanka Lake area, has shown that it is in fact a junior synonym of $H$. submuticus. Our record is appearingly the first one from Kamchatka.

\section{Hydroporus tristis (PAYKULL)}

Dytiscus tristis PAYKULL, 1798:232 (orig. descr.).

Hydroporus tristis (PAYKULL, 1798): NILSSON \& KHOLIN 1994:147 (Sakhalin).

New record: 2(3).

The distribution of $H$. tristis is Holarctic, and it is known from the Magadan Terr., Sakhalin, Hokkaido, and the South Kurils. Our record is apparently the first one from Kamchatka.

\section{Hydroporus uenoi NAKANE}

Hydroporus uenoi NAKANE, 1963:25 (orig. descr.); NILSSON \& NAKANE 1993:424 (descr.); NIISSON \& SATÔ 1993:92 (Sakhalin).

Hydroporus striola (GYLIENHAL, 1826): BALFOUR-BROWNE 1947:439 (misident.).

Hydroporus eugeniae ZATIZEV, 1909: ZMMMERMANN 1931:120 (misident., Kamchatka); ZATrZEv 1953:163 (in part, misident., Kamchatka); LAFER 1989:240 (misident., Kamchatka); ZASYPKINA et al. 1996:20 (misident., Kamchatka River).

New records: $4(5), 8(1)$.

Together with $H$. ijimai NILSSON \& NAKANE, this species form a complex that is known from NE China, Primorye, Sakhalin, South Kurils, Hokkaido and Honshu. We suggest that the literature records of $H$. eugeniae from Kamchatka are based on misidentifications of $H$. uenoi.

\section{Hydroporus umbrosus (GYLLENHAL)}

Hyphydrus umbrosus GYLLENHAL, 1808:538 (orig. descr.).

Hydroporus umbrosus (GYLLENHAL, 1808): ZIMMERMANN 1931:104 (Kamchatka)

New records: $6(16), 8(22)$.

The distribution covers most of North and Central Europe and Siberia to Primorye, Kamchatka, and the northern Kurils.

\section{Oreodytes alpinus (PAYKULL)}

Dytiscus alpinus PAYKULL, 1798:226 (orig. descr.).

Oreodytes alpinus (PAYKULL, 1798): LAFER 1989:214 (Kamchatka); ZASYPKINA et al. 1996:21 (Kamchatka River).

New record: Bystraya River, lower part, 30.viii.1972, 2 females, leg. NIKOLAEVA (IBV). 
LAFER (1989) synonymized $O$. dauricus (MOTSCHULSKY) with $O$. alpinus, leaving it open which of the two species that occur in Kamchatka. ALARIE (1993) associated $O$. dauricus with the alaskanus-clade of the genus, whereas $O$. alpinus belongs to another clade. One characteristic feature of the alaskanus-clade is the emarginate female last abdominal sternite; not found in $O$. alpinus. As the two females seen from Kamchatka belong to $O$. alpinus, our conclusion is that $O$. dauricus does not occur in this Peninsula.

\section{Oreodytes okulovi LAFER}

Oreodytes okulovi LAFER, 1988:52 (orig. descr.).

New record: Penzhina River at Kamenskoye, 16.viii.1972, 1 ind., leg. NIKolaEVA (IBV).

This species was previously known only from the type locality in the south Sikhote-Alin in Primorye. The new record expands the distributional range to include also Kamchatka.

\section{Oreodytes sanmarkii (C. R. SAHLBERG)}

Hyphydrus sanmarkii C. R. SAHLBERG, 1826:172 (orig. descr.).

Hyphydrus rivalis GYLLENHAL, 1827:384 (orig. descr.).

Oreodytes rivalis (GYLLENHAL, 1827): ZAITZEV 1953:186 (Kamchatka); LAFER 1989:242 (Kamchatka); ZASYPKINA et al. 1996:21 (Kamchatka).

New record: Bystraya River, lower part, 30.viii.1972, 3 inds, leg. NIKOLAEVA (IBV).

This Holarctic species is known from Primorye, Sakhalin, Hokkaido, the South Kurils and Kamchatka.

\section{Stictotarsus multilineatus (FALKENSTRÖM)}

Potamodytes griseostriatus Var. multilineatus FALKENSTRÖM, 1922:16 (orig. descr.).

Stictotarsus multilineatus (FALKENSTRÖM, 1922): NILSSON \& ANGUS 1992: 287 (class.).

Deronectes griseostriatus (DE GEER, 1774): ZMMMERMANN 1933:156 (misident., Kamchatka).

Potamonectes griseostriatus (DE GEER, 1774): ZIMMERMANN 1925:3 (misident., Kamchatka); ZAITZEV 1953:196 (misident., Kamchatka); LAFER 1989:242 (misident., Kamchatka); ZASYPKINA et al. 1996:21 (misident., Kamchatka River).

New record: 2(1).

This species belongs to a complex of cryptic species recognized primarily on karyotypic characters. No chromosome studies have so far been performed on Asian populations, and it can only be assumed that the Kamchatka and north Kuril records refer to $S$. multilineatus as this species seems to be distributed along the northernmost Palearctic from Scandinavia to Kamchatka. No karyotypic studies have been made on North American material.

\section{Subfamily Colymbetinae \\ Agabus affinis (PAYKULL)}

Dytiscus affinis PAYKULL, $1798: 211$ (orig. descr.).

Agabus affinis (PAYKULL, 1798): ZATTZEV 1953:239 (Kamchatka); LAFER 1989:245 (Kamchatka); ZASYPKINA et al. 1996:21 (Kamchatka).

We have not been able to verify the literature records of this species from Kamchatka. A reexamination would be motivated from the fact that several new species of this group have been 
described from the Far East of Russia more recently (NILSSON 1994b). However, as specimens of A. affinis were seen from Primorye, the occurrence in Kamchatka is not unexpected.

\section{Agabus arcticus (PAYKULL)}

Dytiscus arcticus PAYKULL, 1798:201 (orig. descr.).

Gaurodytes punctipennis J. SAHLBERG, 1880:56 (orig. descr.).

Agabus arcticus (PAYKULL, 1798): LARSON 1989:899 (distr.).

Gaurodytes arcticus (PAYKULL, 1798): ZMMMERMANN 1934:195 (Kamchatka); ZArTZEV 1953:245 (Kamchatka); LAFER 1989:245 (Kamchatka); ZASYPKNA et al. 1996:21 (Kamchatka).

A circumboreal to -polar species that in North America is known from western Alaska to Labrador and northern Newfoundland. The Palearctic range extends from NW Europe and eastwards to Mongolia and Kamchatka and the northern Kurils. We have not seen any specimens from Kamchatka, although our material from the North Kurils cited below provide support for the literature records given above.

\section{Agabus balkei FERY \& NILSSON}

Agabus balkei FERY \& NILSSON, 1993:103 (orig. descr.).

Agabus erichsoni GEMMNGER \& HAROLD, 1868: FERY \& NILSSON, 1993:103 (in part, misident.).

Gaurodytes nigroaeneus (ERICHSON, 1837): ZIMMERMANN 1925:3, 1934:189 (misident., Kamchatka).

Gaurodytes subtilis (ERICHSON, 1837): ZASYPKINA et al. 1996:21 (misident., Kamchatka River).

Colymbetes oceanicus MoTschULSKY, 1853:8 (nomen nudum, Kamchatka).

New records: $3(1), 8(13)$.

This species was earlier not separated from the very similar A. erichsoni. ZIMMERMANN (1925) recorded A. erichsoni from Kamchatka, and based on 3 females in NRM FERY \& NILSSON (1993) reproduced this record. However, as females of balkei and erichsoni cannot be separated, and males of only balkei so far have been found in Kamchatka, it is more parsimonous to interpret ZIMMERMANN's record as referring to balkei. The occurrence of also A. erichsoni in Kamchatka is, however, not unexpected.

\section{Agabus biguttulus (THOMSON)}

Gaurodytes biguttulus THOMSON, 1867:110 (orig. descr.); ZIMMERMANN 1925:3 (Petropavlovsk); 1934:193 (Kamchatka).

Agabus biguttulus (THOMSON, 1867): NLLSSON \& HoLMEN 1995:101 (descr.).

The specimen that ZIMMERMANN's Kamchatka record was based on was examined by the senior author in NRM several years ago. However, it could now not be found for reexamination, and we find it highly possible that it is misidentified as several species have been described in this group more recently.

\section{Agabus clypealis (THOMSON)}

Gaurodytes clypealis THOMSON, 1867:107 (orig. descr.).

Agabus clypealis (THOMSON, 1867): LARSON 1991:1259 (distr.).

New record: Bolscherjetsk 27.vi.1917 leg. Y. WUORENTAUS, 3 inds MZH, 1 male ZSM.

The delimitation of this species is problematic. LARSON (1991) assigned Nearctic specimens from northwestern Canada to $A$. clypealis. At least some of the literature records from Siberia seemingly refer to other species (NILSSON 1994c). In Europe, A. clypealis is a rare species known from 
northern Germany, Poland, Denmark, Fennoscandia and Russia (BALKE \& HENDRICH 1987). We have preliminary assigned specimens from Kamchatka and North Kurils to this species sensu LARSON (1991).

\section{Agabus costulatus (MotscrulsKY)}

Colymbetes costulatus MOTSCHULSKY, 1859:541 (orig. descr.).

Gaurodytes tunkinensis ZIMMERMANN, 1928:178 (orig. descr.).

Agabus costulatus (MOTSCHULSKY, 1859): JAKOBSON 1908:430 (Kamchatka); ZAITZEV 1915:267 (Kamchatka); NiLSSON 1990:153 (descr.).

Gaurodytes costulatus (MOTSCHULSKY, 1859): ZATrZEV 1953:248 (Kamchatka); LAFER 1989:247 (Kamchatka); ZASYPKINA et al. 1996:22 (Kamchatka).

New records: $5(1), 7(1 / 3)$.

This large eastern Palearctic confinis-group species is hard to separate from $A$. thomsoni. Generally, specimens of costulatus are slightly larger and broader than those of thomsoni (NILSSON 1990). We have assigned the two specimens we have seen to costulatus after a comparison with the longer series seen from the North Kurils (see below).

\section{Agabus coxalis SHARP}

Agabus coxalis SHARP, 1882:535 (orig. descr.).

Gaurodytes coxalis (SHARP, 1882): LAFER 1989:246 (key, Kamchatka); ZASYPKNA et al. 1996:21 (Kamchatka).

Gaurodytes coxalis ermaki ZATTZEV, 1953:259 (orig. descr., Kamchatka).

This Holarctic species is in North America confined to the northwest. The Palearctic range extends from the Ural and Caucasus and eastwards to Kamchatka. According to ZAITZEV (1953) the Kamchatka populations belong to the subspecies $A$. c. ermaki. We have not been able to verify the presence of this species in Kamchatka. However, as it is highly characteristic, it is not likely to be misidentified.

\section{Agabus discolor (HARRIS)}

Colymbetes discolor HARRIS, 1828:164 (orig. descr.)

Agabus levanderi HELLÉN, 1929:40 (orig. descr.); syn. nov.

Agabus discolor (HARRIS, 1828): LARSON 1991:1272 (descr.).

Gaurodytes clypealis THOMSON, 1867: ZMMMERMANN 1934:208 (misident., ?Kamchatka, Ozernaja).

New records: $3(1), 8(4), 9(7)$.

Ozernaja $10^{*} \mathrm{ZSM}$.

A northern circumboreal species that is known from northern Fennoscandia to Kamchatka in the Palearctic and is transcontinental in North America. It belongs to a complex of chiefly Nearctic species. According to LARSON (1991), eastern Palearctic specimens of A. levanderi cannot be separated from $A$. discolor (HARRIS) specimens from western Alaska. NILSSON (1994c) showed that some of the Palearctic specimens assigned to discolor and levanderi by various authors in fact belong to a separate species, $A$. angusi. As a result, the relative width of the metasternal wing of Palearctic discolor populations is now within the range of the Nearctic ones. As we have seen one male of this species labelled "Ozernaja" in coll. ZIMMERMANN, his Kamchatka record of $A$. clypealis most probably refers to $A$. discolor. 


\section{Agabus opacus AUBE}

Agabus opacus AUBÉ, 1837:173 (orig. descr.).

Gaurodytes opacus (AUBÉ, 1837): LAFER 1989:244 (key).

Gaurodytes mimmi J. SAHLBERG, 1875:182 (orig. descr.); ZATTZEV 1915:267 (Kamchatka).

Agabus sibericus SHARP, 1882:519 (orig. descr.); preoccupied by J. SAHLBERG 1880.

Agabus sharpi JAKOBSON, 1908:430 (replacement name for Agabus sibericus SHARP, 1882, not J. SAHLBERG, 1880); LARSON \& NLSSON 1985:124 (syn.).

Agabus sachalinensis KaMrYa, 1938:37 (orig. descr.).

New records: $5(2), 7(1)$.

In North Europe, this species prefers temporary forest pools. The world distribution is northern Holarctic. It is known in the Far East from Primorye, Sakhalin and Kamchatka.

\section{Agabus tristis AuBÉ}

Agabus tristis AUBÉ, 1838b:356 (orig. descr.); NILsson 1990:159 (syn.).

Agabus kurilensis KAMTYA, 1938:35 (orig. descr., Shumshu).

Gaurodytes tristis (AUBÉ, 1838): ZMMMERMANN 1934:181 (Kamchatka).

New records: 2(3), 9(1).

Ozernaja 30.vii. 1917, leg. WUORENTAUS, 1 ind $\mathrm{ZMH}$.

This Holarctic species is widespread in Siberia and known also from Magadan, Chukotka and the North Kurils (LAFER 1989).

\section{Ilybius angustior (GYLLENHAL)}

Dytiscus angustior GYLLENHAL, 1808:500 (orig. descr.).

Ilybius angustior (GKLLENHAL, 1808): JAKOBSON 1908:428 (Kamchatka); ZATTZEV 1953:280 (Kamchatka); ZASYPKINA et al. 1996:23 (Kamchatka).

Ilybius aenescens THOMSON, 1870: ZIMMERMANN 1925:3 (misident; Tarja, Avatcha Bay).

New record: $4(1)$.

A Holarctic species with a chiefly boreal range. In North America it is transcontinental, known from Alaska to Newfoundland and south along the Rocky Mountains to New Mexico. In the Palearctic known from Fennoscandia and eastwards to North Sakhalin, Kamchatka and North Kurils. A specimen from Kamchatka was present in coll. MOTSCHULSKY according to ZAITZEV (1915). A single male in NRM from Kamchatka was misidentified by ZIMMERMANN (1925) as $I$. aenescens.

\section{Ilybius chishimanus KôNo}

Ilybius chishimanus KôNO, 1944:80 (orig. descr.); NiLsson 1994d:57 (syn.).

Ilybius weymarni J.BALFOUR-BROWNE, 1947:446 (orig. descr.).

? Ilybius gibbus MOTSCHULSKY, 1852:7 (nomen nudum, Kamchatka).

? Ilybius bergeri ZAITZEV, 1915:260 (nomen nudum).

New records: $4(3), 6(1)$.

This species was first described from Paramushir. It occurs from Irkutsk and eastwards to North China, Primorye, Kamchatka and North Kurils (NILSSON 1994d). ZATTZEV (1915) identified MOTSCHULSKY's Kamchatka specimens as belonging to his $I$. bergeri that he intented to describe from material from the South Ussuri Region. We here suggest that these specimens belonged to I. chishimanus. 


\section{Ilybius discedens SHARP}

Ilybius discedens SHARP, 1882:557 (orig. descr.); ZMMMERMANN 1925:3 (Petropavlovsk); LARSON 1987:350 (descr.).

New record: $6(1)$.

ZIMMERMANN's (1925) record of this species was overlooked by subsequent authors. Consequently, I. discedens has been known as strictly Nearctic (LARSON 1987). As we have confirmed the presence of this species in Kamchatka and the Island of Paramushir there is no longer any doubt of its Holarctic distribution.

\section{Colymbetes dahuricus AUBÉ}

Colymbetes dahuricus AUBÉ, 1837:99 (orig. descr.); JAKOBSON 1908:433 (Kamchatka); ZArTZEV 1915:276 (Kamchatka); GsCHWENDTNER 1936:94 (Kamchatka); ZAITZEV 1953:297 (Kamchatka); LAFER 1989:250 (Kamchatka); ZASYPKINA et al. 1996:23 (Kamchatka).

Colymbetes paykulli ERICHSON, 1837: ZMMMERMANN 1925:3 (misident, Kamchatka).

New record: $6(4)$.

This northern Holarctic species is widespread in East Siberia and in the Far East of Russia, including Primorye. One female in NRM was misidentified by ZIMMERMANN (1925) as C. paykulli.

\section{Colymbetes dolabratus (PAYKULL)}

Dytiscus dolabratus PAYKuLL, 1798:204 (orig. descr.).

Colymbetes groenlandicus AUBÉ, 1838b:233 (orig. descr.).

Colymbetes thomsoni SHARP, 1882:628 (orig. descr.).

Colymbetes dolabratus (PAYKULL, 1798): JAKOBSON 1908:433 (Kamchatka); ZATTZEV 1915:275 (Kamchatka); ZIMMERMANN 1925:3 (Kamchatka); GscrwWENDTNER 1936:96 (Kamchatka); LAFER 1989:250 (Kamchatka); ZASYPKNA et al. 1996:23 (Kamchatka).

New records: $8(1), 9(1)$.

A circumpolar species that in North America occurs along the northern edge of the continent from Alaska to Quebec. On Greenland north to about $75^{\circ} \mathrm{N}$. In Eurasia it ranges from Iceland and Fennoscandia to Kamchatka, Komandorskiye Islands, and North Kurils, in arctic and northern boreal regions.

\section{Rhantus notaticollis (AUBÉ)}

Colymbetes notaticollis AUBÉ, 1837:107 (orig. descr.).

Rhantus nigriventris MOTSCHULSKY, 1860:101 (orig. descr., Kamchatka).

Rhantus notaticollis (AUBÉ, 1837): JAKOBSON 1908:432 (Kamchatka); ZAITZEV 1915:273 (Kamchatka); ZMMERMANN 1925:3 (Kamchatka); GSCHWENDTNER 1936:65 (Kamchatka);ZAITZEV 1953:289 (Kamchatka); LAFER 1989:250 (Kamchatka); ZASYPKINA et al. 1996:23 (Kamchatka).

This widespread Palearctic species is known also from Primorye, Sakhalin, Hokkaido, and the Kurils. A single female from Kamchatka identified by A. ZIMMERMANN was seen in NRM. It was reported from Kamchatka already by MOTSCHULSKY (1860).

\section{Rhantus suturellus (HARRIS)}

Colymbetes suturellus HARRIs, 1828:164 (orig. descr.).

Rhantus suturellus (HaRris, 1828): KôNO 1944:81 (Paramushir). 
New records: $2(2 / 2), 6(1 / 1), 8(7)$.

A circumboreal species that is transcontinental in North America where it is known from Alaska to Nova Scotia and south to New Jersey, Wyoming and Washington. In the Palearctic known from France and Austria to Great Britain and Fennoscandia, and eastwards to East Siberia, Magadan, Kamchatka and North Kurils. Our record is appearingly the first one from Kamchatka.

\section{Subfamily Dytiscinae}

\section{Graphoderus perplexus SHARP}

Graphoderus perplexus SHARP, 1882:695 (orig. descr.); LARSON 1975:407 (distr.).

New record: $6(5 / 3)$.

Our record from Kamchatka is the first Palearctic one of this otherwise Nearctic species (LARSON 1975). It is very similar to the Palearctic $G$. zonatus, but differs chiefly in the lower number of adhesive discs on the male pro- and mesotarsi. WALLIS (1939) gave some additional differences. The five Kamchatka males had 27-30 small discs on the protarsus (excl. 3), and 14-17 on the mesotarsus arranged in two regular rows. Corresponding values for three males from Urup are 6166 and $27-31$.

\section{Acilius canaliculatus (NICOLAI, 1822)}

Dytiscus canaliculatus NICOLAI, 1822:29 (orig. descr.).

Acilius canaliculatus (NICOLAI, 1822): JAKOBSON 1908:435 (?Kamchatka); ZATTZEV 1953:319 (Kamchatka); LAFER 1989:252 (Kamchatka); ZASYPKINA et al. 1996:23 (Kamchatka).

New record: $8(/ 6)$.

This northern Palearctic species occurs from France to Great Britain and Scandinavia, and eastwards to the Far East of Russia including Sakhalin and Kamchatka.

\section{Dytiscus circumcinctus AHRENS}

Dytiscus circumcinctus AHRENS, 1811:67 (orig. descr.); ZIMMERMANN 1925:3 (Kamchatka); ZATTZEV 1953:331 (Kamchatka); LAFER 1989:253 (Kamchatka); ZASYPKINA et al. 1996:23 (Kamchatka).

Macrodytes circumcinctus (AHRENS, 1811): JAKOBSON 1908:435 (Kamchatka).

Dytiscus ooligbuckii KIRBY, 1837:74 (orig. descr.).

Dytiscus confusus MOTSCHULSKY, 1860:101 (orig. descr., Kamchatka).

A single male from Kamchatka of this Holarctic species identified by A. ZIMMERMANN was seen in NRM. It was reported from Kamchatka already by MoTSCHULSKY (1860).

\section{Dytiscus dauricus GEBLER}

Dytiscus dauricus GEBLER, 1832:29 (orig. descr.); ZMMMERMANN 1925:3 (Kamchatka); RoUGHLEY 1990:483 (syn., map); ZASYPKINA et al. 1996:23 (Kamchatka).

Macrodytes dauricus (GEBLER, 1832): JAKOBSON 1908:435 (Kamchatka).

Dytiscus obscurus GSCHWENDTNER, $1922: 93$ (orig. descr.).

Dytiscus frontalis MoTschUlsky, 1860:101 (orig. descr., Kamchatka); GsCHWENDTNER 1938:50 (Kamchatka).

Macrodytes frontalis (MOTSCHULSKY, 1860): JAKOBSON 1908:436 (Kamchatka).

New records: $1(/ 5), 6(1), 8(1 / 2)$. 
This Holarctic species is widespread in the East Palearctic. It is known both from Sakhalin, Hokkaido, the Kurils and Kamchatka. All females seen from the Kurils and Kamchatka belong to the smooth morph. A sulcate female from Hokkaido differed also in having much narrower marginal yellow bands on the pronotum when compared to Kuril specimens. This difference may represent a more general pattern as it is valid also for the Japanese specimens shown in MORI \& KrTAYAMA (1993). Japanese populations have been given subspecific status as $D$. dauricus zaitzevi NAKANE, 1990.

\section{Additional records for the Kuril Islands and Sakhalin}

Hygrotus impressopunctatus (SCHALLER)

IT: 29(3/3), 72(2).

SK: $3(2), 5(1)$.

First records for Iturup and North Sakhalin.

Hygrotus inaequalis (FABRICIUS)

SK: 2(7), 4(22).

First records for North Sakhalin.

Hydroporus breviusculus PoppIUs

SK: 1(16), 4(5), 5(4), 6(1), 7(1), 8(3).

First records for North Sakhalin.

Hydroporus fuscipennis SCHAUM

SK: 3(11), 4(6), 5(41), 6(20), 7(3), 8(1), 9(2).

First records for North Sakhalin.

Hydroporus morio AUBÉ

KH: 42(3). - MA: 56(53/6). - MK: 70(1), 76(71), 79(1), 81(67). - ON: 14(31), 16(52), 18(6), 28(87), 29(24). - PA: 24(21), 60(5), 69(2), *2(22/1), *3(7), *5(1), *6(2), *8(1), *11(2). - SA: 12(1), 15(14), 49(24), 51(20). - SU: 29(5), 48(3).

SK: $9(7)$.

First records for Kharimkotan, Makanrushi, Matua, and Onckotan

Hydroporus nigellus MANNERHEIM

MK: 76(7), 79(2), 81(43). - PA: 2(25), 9(1), 10(8), 23(5), 24(1), 60(28), 67(3), 69(2), 71(5), *1(1), $* 4(13), * 7(2), * 8(24), * 9(3), * 10(24), * 11(2)$. SU: 29(7), 30(1), 34(14), 41(29), 45(8), 47(2), $48(1), * 1(23), * 2(7)$.

SK: $3(2), 4(1), 5(2), 6(2), 9(4), 10(2)$.

First records for Sakhalin and the Kurils: Makanrushi, Paramushir, and Shumshu.

\section{Hydroporus notabilis LECONTE}

PA: 2(1), 23(2), 60(3), 67(1), 69(4), *11(3). - SU: 48(6), *1(5), *2(5).

First records for the Kurils: Paramushir and Shumshu.

Hydroporus saghaliensis TAKIZAWA

Kunashir: NW shore, Rudnoye village, by Severyanka River, in water bodies on the road, 26.viii.1997, 1 fe, leg. Y. MARUSIK.

First record for Kunashir. 
Hydroporus submuticus THOMSON

PA: *6(1). - SU: $48(2)$.

SK: 1(3).

First record for the Kurils: Paramushir and Shumshu.

Hydroporus tristis (PAYKULL)

IT: 72(2). - UR: 67(2).

SK: $4(17), 5(1), 9(17)$.

First records for North Sakhalin and the Kurils: Iturup and Unup.

Hydroporus uenoi NAKANE

IT: 7(1), 8(1). - UR: 67(13).

SK: 1(13), 2(9), 3(1), 4(1), 6(2).

First records for Iturup and North Sakhalin.

Stictotarsus multilineatus (FALKENSTRÖM)

KH: 33(31/19), 35(96/32), 42(12/7). - ON: 14(23/27), 18(/1). - PA: 70(4), *2(10), *5(1/2). - SA: 51(2). - SU: $47(5), * 1(1)$.

First records for Kharimkotan, Onekotan and Shiashkotan.

Agabus arcticus (PAYKULL)

PA: 23(3), 42(5), 48(11), 69(74), 70(3/1), *7(5). - SU: 47(11), *1(21/1).

Agabus clypealis (THOMSON)

PA: *6(25). - SU: 48(8).

First record for the Kurils: Paramushir and Shumshu.

Agabus confinis (GYLLENHAL)

PA: 2(5), 52(1), *6(1). - SU: 48(1).

First record for the Kurils: Paramushir and Shumshu.

IT: $72(1)$.

Agabus congener (THUNBERG)

SK: $4(1), 5(3), 6(6), 9(2)$.

First record for Iturup and North Sakhalin.

Agabus conspicuus SHARP

IT: 7(57), 8(12), 10(1). - UR: 67(23).

Agabus costulatus (MOTSCHULSKY)

PA: 24(62), 60(24), 67(16), *3(2/2). - SU: 29(1), 31(2), 34(2), 41(2).

First record for the Kurils: Paramushir and Shumshu.

Agabus discolor (HARRIS)

PA: *2(1). - SU: 31(7).

First record for the Kurils: Paramushir and Shumshu.

Agabus erichsoni GEMMINGER \& HAROLD

SK: 4(1), 5(2).

First records for North Sakhalin. 
Agabus japonicus SHARP

IT: 7(9), 8(6), 29(8). - KH: 33(1). - MK: 76(4), 81(26). - ON: 14(3/1), 15(5), 16(3), 18(24), 26(/1), 28(10), 29(42). - SA: 12(9), 15(/1), 15PO(5), 49(44), 51(13/16). - UR: 67(36).

SK: $1(1)$.

First records for Iturup, Kharimkotan, Makanrushi, Onekotan, and Shiashkotan.

Agabus kholini NILSSON

SK: 4(12).

First record for Sakhalin.

SK: 7(2).

Agabus opacus AUBÉ

First record for North Sakhalin.

PA: 2(2).

Agabus thomsoni J. SAHLBERG

Agabus tristis AUBÉ

PA: $60(8 / 1), * 2(2 / 3), * 3(1 / 4), * 5(/ 2), * 7(2), * 8(21 / 3)$.

Ilybius angustior (GYLLENHAL)

ON: 17(5), 18(2). - PA: 2(1), 4(3), 6(1), 23(29), 48(1), 52(26), 69(8), 71(1), *1(1), *2(2), *4(7). SU: 30(22), 31NM(6), 31TIR(5), 41(5), 47(2), 48(1), *1(24).

SK: $1(1), 6(/ 7), 7(1)$.

First records for Sakhalin and Onekotan.

Ilybius apicalis SHARP

IT: 29(7). - KU: 77(1). - UR: 67(92).

Ilybius chishimanus KôNO

PA: 9(1), 10(3), 11(13), 35(1), 36(7), 42(4), 48(12), 69(28), 71(1), *1(3).

PA: *6(11).

Ilybius discedens SHARP

First record for the Kurils: Paramushir.

IT: $8(1)$

Ilybius nakanei NILSSON

SK: $1(1 / 5), 9(/ 14)$.

First records for Iturup and North Sakhalin.

Colymbetes dahuricus AUBÉ

KH: 35(/1), 42(3). - MK: 79(4), 81(11/3). - ON: 17(1), 28(8), 29(34). - SA: 13(2), 15(1), 49(2), $51(3 / 9)$.

First record for the Kurils: Kharimkotan, Makanrushi, Onekotan, and Shiashkotan.

Colymbetes dolabratus (PAYKULL)

PA: 2(3), 4(1), 6(1), 23(78), 48(4), 67(4/2), *2(/1), *5(3/1), *6(/1), *7(2), *9(1/11), *10(/2). - SU: 29(28/6), 30(3/2), 31NM(2), 31TIR(3), 41(9), 47(18), *2(/4).

Colymbetes tolli ZAITZEV

SK: 7(2), 8(1).

First records for North Sakhalin. 


\section{Rhantus notaticollis (AUBÉ)}

IT: $7(/ 1), 8(1 / 2), 29(1), 72(5)$.

SK: $5(1)$.

First records for Iturup and North Sakhalin.

Rhantus suturalis (MACLEAY)

IT: $6 \mathrm{C}(1), 7(6 / 1), 8(6), 10(1), 72(1)$.

First records for Iturup.

Rhantus suturellus (HARRIS)

ON: 17(3). - PA: 8(1), 10(1/3), 60(1), 65(/5). - SU: 30(1/5), 31TIR(1/3), *1(1/2).

First records for Onekotan and Shumshu. ZIMMERMAN \& SMITH (1975) noted the presence of specimens from Alaska and especially the Kenai Peninsula with the anterior and posterior black pronotal bands expanded and fused medially. The two males from Onekotan displayed this colour pattern, whereas the single female had the normal coloration. The presence of this colour morph on both sides of the Bering Strait provides a strong indication of gene flow across this barrier.

Dytiscus dauricus GEBLER

IT: 7(1), 8(1), 29(/1). - PA: 9(/1), 10(1), 11(3), 23(9), 42(4), 45(/1), 64(4), 69(54), *2(/1), *5(/8), $* 7(/ 4), * 11(/ 2)$. - SU: 29(1), 30(/10), 31TIR(2/5), 41(2), *1(3/2). - UR: 67(2/1).

SK: $6(2)$.

First record for North Sakhalin.

Dytiscus delictus (ZAITZEV)

One specimen from Paramusir (Okeanskoje Aug. 1923) was seen in USNM by R.E. ROUGHLEY (in litt.). This is the first record from the Kurils.

SK: 2(1).

Acilius canaliculatus (NICOLAI)

First record for Sakhalin.

\section{Discussion}

Currently, 62 species of Dytiscidae are known from Sakhalin, the Kuril Islands and the Kamchatka Peninsula (Tab. 1). The faunas of these three regions are of comparable size, i.e. 39 species in Sakhalin, 36 in the Kuril Archipelago, and 38 in Kamchatka. Additional sampling of these faunas will no doubt raise these values. Highly expected to occur also in Kamchatka are the species known from the North Kuril Islands, but not from the peninsula itself, i.e. Agabus confinis and $A$. thomsoni. Three species that earlier had this kind of distribution were expected to be found in Kamchatka by NiLsSON et al. (1997). All three species, viz. Agabus tristis, Ilybius chishimanus and Rhantus suturellus are here indeed reported from Kamchatka for the first time. No similar gaps are known from the south end of the Kuril island chain, i.e. all species known from the South Kurils have also been found in Sakhalin and/or Hokkaido (Tab. 1). On the other hand, there are seven species known from both the south and north Kuril source areas, Kamchatka and Sakhalin and/or Hokkaido, that are seemingly absent from the Kuril islands. Especially striking is the absence of Hygrotus inaequalis and Hydroporus fuscipennis.

A comparison with the species composition of the individual Kuril islands with that of the source areas produces relatively tight patterns, i.e. species that occur in one of the source areas and in a series of adjacent islands. Applying KRYVOLUTSKAJA's (1973) division of the Kuril islands into three groups based on their insect faunas (cf. Tab. 1), results in a species-poor central group with eight species, and richer south and north groups with 16 and 21 species, respectively. Of the six 
species that probably have colonized the central islands from the north, Hydroporus morio have been most successful, reaching all the way to Ketoi. The same island was seemingly reached from the south by Agabus conspicuus, whereas A. japonicus seemingly has successfully colonized the central islands north to Makanrushi.

Based on their distributions, the species found in Kamchatka plus Sakhalin and the Kurils were classified into four groups, viz. Holarctic, Palearctic, East Palearctic and Japano-Kurilian (Tabs 1 $\&$ 2). The last group includes species found on one or more of the north-east Pacific islands, but absent from the mainland outside Korea. The Holarctic element is strongly represented in the Kamchatkan fauna, including three out of five species found in the peninsula. In Sakhalin only one out of three species has a Holarctic distribution, and instead the Palearctic and East Palearctic elements are more important. Moreover, the Japano-Kurilian group of species that includes a high proportion of lotic species is totally absent from Kamchatka.

The presence in Kamchatka of otherwise strictly Nearctic species like Ilybius discedens and Graphoderus perplexus stresses the importance of extending the faunal analysis to the North American parts of Beringia. However, no detailed faunistical account is available for the 92 species of Dytiscidae known from Alaska and the Aleutian Islands (BOUSQUET 1991). Comparing faunas from the two continents surrounding Beringia would also stress the need for more detailed taxonomic studies, including the analysis of geographic variation in morphology among island and mainland populations.

\section{References}

AHRENS A. 1811: Beschreibung der grossen Wasserkäfer-Arten der Gegend um Halle in Sachsen (Dytici). Neue Schriften der Naturforschenden Gesellschaft zu Halle, 1(6): 47-59.

ALARIE, Y. 1993: A systematic review of the North American species of the Oreodytes alaskanus clade (Coleoptera: Dytiscidae: Hydroporinae). - Can. Ent., 125: 847-867.

ANGUS, R. B. 1985: Suphrodytes Des Gozis a valid genus, not a subgenus of Hydroporus ClaIRVILLE (Coleoptera: Dytiscidae). - Ent. scand., 16: 269-275.

AUBÉ, C. 1836-1838a: Hydrocanthares. - In: DEJEAN, P. F. Iconographie et histoire naturelle des Coléoptères d'Europe. Vol. 5. - Paris, XI + 416 pp.

AUBÉ, C. 1838b: Hydrocanthares et Gyriniens. - In: DEJEAN, A. Species géneral des Coléoptères de la collection de M. le Comte Dejean. Vol. 6. - Paris.

BALFOUR-BROWNE, J. 1947 (1946): The aquatic Coleoptera of Manchuria (WEYMARN collection). - Annls Mag. nat. Hist. (11), 13: 433-460.

BALKE, M. \& HENDRICH, L. 1987: Zwei seltene Agabus aus Berlin (W) (Coleoptera: Dytiscidae). - Ent. Zeitschr., 97: 324-328.

Bousquet, Y. 1991: Checklist of beetles of Canada and Alaska. - Agric. Can. Publ. 1861/E, 430 pp.

FABRICIUS, J. C. 1777: Genera insectorum. - Chilonii, 310 pp.

FALKENSTRO̊M, G. 1922: Stockholmstraktens Vatten-Coleoptera. - Ent. Tidskr., 43: 10-32.

FALL, H. C. 1919: The North American species of Coelambus. - Mount Vernon, New York, 20 pp.

FERY, H. \& NLSSON, A. N. 1993: A revision of the Agabus chalconatus- and erichsoni-groups (Coleoptera: Dytiscidae), with a proposed phylogeny. - Ent. scand., 24: 79-108.

GEBLER, F. von 1832: Notice sur les Coléoptères qui se trouvent dans le district des mines de Nertchinsk, dans la Sibérie orientale, avec la description de quelques espéces nouvelles. - Nouv. Mém. Soc. imp. Naturalist. Moscou, 8: 25-78.

GSCHWENDTNER, L. 1922: Beiträge zur Kenntnis der Dytiscidae Transbaikaliens. - Wiener ent. Zeitung, 39: 92-94.

GSCHWENDTNER, L. 1936: Monographie der paläarktischen Dytiscidae. VII. Colymbetinae (Colymbetini: Rhantus, Nartus, Melanodytes, Colymbetes, Meladema). - Koleopt. Rdschau, 22: 61-102. 
GSCHWENDTNER, L. 1938: Monographie der paläarktischen Dytiscidae. IX. Dytiscinae. - Koleopt. Rdschau, 24: 33-76.

GuIGNOT, F. 1945: Dix-huitième note sur les Hydrocanthares. - Bull. Soc. ent. Fr., 1945: 18-23.

GYLlENHAL, L. 1808: Insecta Suecica descripta. Classis I. Coleoptera sive Eleutherata. Pars 1. - Scaris, XII $+572 \mathrm{pp}$.

GYLLENHAL, L. 1813: Insecta Suecica descripta. Classis I. Coleoptera sive Eleutherata. Pars 2. - Lipsiae, XX $+660 \mathrm{pp}$.

GYLlenHAL, L. 1827: Insecta Suecica descripta. Classis I. Coleoptera sive Eleutherata. Pars 4. - Lipsiae, X $+761 \mathrm{pp}$.

JAKOBSON, J. J. 1908: Coleoptera of Russia and eastern Europe. St. Petersburg. [In Russian.]

HARRIS, T. W. 1828: Contributions to entomology. No. VI. - New England Farmer, 7: 164.

HeLLÉN, W. 1929: Zur Kenntnis einiger Dytisciden Finnlands. - Notulae ent., 9: 34-46.

KAMTYA, K. 1938: A systematic study of the Japanese Dytiscidae. - J. Tokyo Nogyo Daigaku, 5: 1-68 + 7 pls.

KIRBY, W. 1837: The insects. -In: RICHARDSON, J. Fauna Boreali-Americana. Part 4. - London, 249 pp.

KôNO, H. 1944: Die Käfer-Fauna der Nord-Kurilen (XI. Beitrag zur Kenntnis der Käferfauna der Kuriln). Cishima Gakujutsu-chôsa-kenkyû-tai Hôkokusho, 1: 74-92.

KrYvolutskaja, G. O. 1973: Entomofauna of the Kuril Islands. Principal features and origin. - Nauka, Leningrad. [In Russian.]

LAFER, G. SH. 1988: Novye vidy zhukov-plavuntzov (Coleoptera, Dytiscidae) s Dalnego Vostoka SSSR. Pp. 52-59. - In: Fauna, sistematika i biologiya presnovodnych bespozvonochnych. - Vladivostok, Akademiya Nauk SSSR.

LAFER, G. SH. 1989: Sem. Dytiscidae - Plavuntzy. - Opredelitel Nasekomych Dalnego Vostoka SSSR, 3(1): 229-253.

LARSON, D. J. 1975: The predaceous water beetles (Coleoptera: Dytiscidae) of Alberta: systematics, natural history and distribution. - Quaest. Entomol., 11: 245-498.

LARSON, D. J. 1987: Revision of North American species of llybius ERICHSON (Coleoptera: Dytiscidae), with systematic notes on Palaearctic species. - J. N. Y. ent. Soc., 95: 341-413.

LARSON, D. J. 1989: Revision of North American Agabus LEACH (Coleoptera: Dytiscidae): introduction, key to species groups, and classification of the ambiguus-, tristis-, and arcticus-groups. - Can. Ent., 121: 861-919.

LARSON, D. J. 1991: Revision of North American Agabus LEACH (Coleoptera: Dytiscidae): elongatus-, zetterstedti-, and confinis-groups. - Can. Ent., 123: 1239-1317.

LARSON, D. J. \& NLSSON, A. N. 1985: The Holarctic species of Agabus (sensu lato) LEaCH (Coleoptera: Dytiscidae). - Can. Ent., 117: 119-130.

LECONTE, J. L. 1850: General remarks upon Coleoptera of Lake Superior, pp. 209-241. - In: AGASSIZ, L. (Ed.). Lake Superior: Its physical character, vegetation and animals. - Boston.

MANNERHEIM, C. G. 1853: Dritter Nachtrag zur Käferfauna der Nord-Amerikanischen Länder des Russichen Reiches. - Bull. Soc. Imp. Natur. Moscou, 26: 95-273.

MOR, M. \& KITAYAMA, A. 1993: Dytiscoidea of Japan. - Kankyo-Kagaku Ltd., Osaka. 217 pp.

MOTSCHULSKY, V. DE 1845: Observations sur le Musée entomologique de l'Université impériale de Moscou. - Bull. Soc. imp. Nat. Mosc. 18: 332-388, pls. 5-7.

MOTSCHULSKY V. DE 1853: Hydrocanthares de la Russie. - Helsingfors, Imprimerie de la Société de Litérature Finnoise, $15 \mathrm{pp}$.

MOTSCHULSKY, V. DE 1859: Coléoptères du gouvernement de Iakoutsk, recuillies par M. PAVLOFSKI. - Bull. Phys. Mat. Acad. St. Petersb., 17: 539-544.

MOTSCHULSKY, V. DE 1860: Coléoptères de la Sibérie orientale et en particulier des rives de l'Amour. - In: SCHRENCK, L. von (ed.). Reisen und Forschungen im Amur-Lande. Vol. 2(2):79-257 + 6 pls. + 1 map.

NAKANE, T. 1963: New or little-known Coleoptera from Japan and its adjacent regions. XVIII. - Fragmenta Coleopterologica, $6: 23-26$.

NiCOLAI, E. A. 1822: Dissertatio inauguralis medica sistens Coleopterorum species agri Halensis. - Halae, $44 \mathrm{pp}$. 
Nilsson, A. N. 1990: Revisional notes on selected East Palaearctic species of Agabus LEACH (Coleoptera, Dytiscidae). - Ent. Tidskr., 111: 149-161.

Nilsson, A. N. 1994a: Revision of the Hydroporus nigellus complex (Coleoptera: Dytiscidae) including multivariate species separation. - Ent. scand., 25: 89-104.

NILsSON, A. N. 1994b: Two new species of Agabus LEACH from East Russia and North China, with notes on other species of the Agabus affinis species group (Coleoptera: Dytiscidae). - Koleopt. Rundschau, 64: 45-50.

Nusson, A. N. 1994c: Two new East Palearctic Agabus species of the adpressus- and confinis-groups (Coleoptera, Dytiscidae). - Ent. fenn., 5: 169-175.

NiLsSON, A. N. 1994d: A revision of the Palearctic Ilybius crassus-complex (Coleoptera, Dytiscidae). - Ent. Tidskr., 115: 55-61.

Nilsson, A. N. 1995: A new Hydroporus species from Kamchatka previously standing as H. brevis $\mathrm{F}$. SAHLBERG (Coleoptera: Dytiscidae). - Koleopt. Rdschau, 65: 23-26.

NILsSON, A. N. \& ANGUS, R. B. 1992: A reclassification of the Deronectes-group of genera (Coleoptera: Dytiscidae) based on a phylogenetic study. - Ent. scand., 23: 275-288.

NILSSON, A. N. \& HolmEN, M. 1995: The aquatic Adephaga (Coleoptera) of Fennoscandia and Denmark. II. Dytiscidae. - Fauna ent. scand., 32: 1-192.

Nilsson, A. N. \& Kholin, S. K. 1994: The diving beetles (Coleoptera, Dytiscidae) of Sakhalin - an annotated checklist. - Ent. Tidskr., 115: 143-156.

Nilsson, A. N. \& LARSON, D. J. 1984: A reexamination of some Dytiscidae (Coleoptera) from Newfoundland and adjacent areas. - Annls ent. fenn., 50: 123-125.

NILsSon, A. N.; MinaKaWA, N. \& OBERg, P. B. H. 1997: The diving beetles of the Kuril Archipelago in the Far East of Russia (Coleoptera: Dytiscidae), - Beitr. Ent., 47: 365-376.

NILSSON, A. N. \& NAKANE, T. 1993 (1992): A revision of the Hydroporus species (Coleoptera: Dytiscidae) of Japan, the Kuril Islands, and Sakhalin. - Ent. scand., 23: 419-428.

Nilsson, A. N. \& SATô, M. 1993: Five Hydroporus species new to Japan and the Kuril Islands, with additional records of other species (Coleoptera: Dytiscidae), - Trans. Shikoku ent. Soc., 20: 87-95.

PAYKull, G. von 1798: Fauna Suecica. Insecta. Vol. 1. - Uppsaliae, X+358 pp.

Popprus, B. 1905: Beiträge zur Kenntniss der Coleopteren-Fauna des Lena-Thales in Ost-Sibirien. I. Haliplidae und Dytiscidae. - Öfv, Finska Vet. - Soc. Förhandl., 47(16): 1-24.

RoUGHLEY, R. E. 1990: A systematic revision of species of Dytiscus LINNAEus (Coleoptera: Dytiscidae). Part 1. Classification based on adult stage. - Quaest. ent, 26: 383-557.

SAHLBERG, C. R. 1826: Dissertatio entomologica insecta fennica enumerans. XII. - Aboae, pp. 169-184.

SAHLBERG, F. 1834: Dissertatio Academica novas Coleopterorum fennicorum species sistens. - Helsingforsiae, $12 \mathrm{pp}$.

SAHLBERG, J. 1875: Enumeratio Coleopterorum carnivororum Fenniae. Notiser ur Sällskapets pro Fauna et Flora Fennica Förhandlingar, 14: 41-200.

SAHLBERG, J. 1880: Bidrag till nordvestra Sibiriens insektfauna. Coleoptera. I. - K. svenska Vetensk.Akad. Handl., 17(4): 1-115+1 pl.

SAHLBERG, J. 1910: Om Hydroporus semenovi JAKowL. och närstående arter. - Meddn Soc. Fauna Flora fenn., 36: 167-176.

SCHALLER, J. G. 1783: Neue Insekten. - Abh. der Hallischen Naturforschenden Gesellschaft, 1: 217-328.

SCHAUM, H. \& KIESENWETTER, H. von, 1868: Coleoptera, Erster Band, zweite Hälften. - In: Erichson, W.F. (ed.). Naturgeschichte der Insekten Deutschlands. - Berlin, 144 pp.

SHARP, D. 1882: On aquatic carnivorous Coleoptera or Dytiscidae. - Scient. Trans. R. Dubl. Soc. (2), 2: 171003.

TAKIZAWA, M. 1933: The Dytiscidae of Japan. Part II (Hydroporinae). - Insecta Matsumurana, 7(4): 165-179.

THOMSON, C. G. 1856: Ofversigt af de arter inom familjen Dytisci, som blifvit anträffade på Skandinaviska halfön. - K. Svenska VetenskAkad. Handl., 1854(12): 181-237.

Thomson, C. G. 1867: Skandinaviens Coleoptera, synoptiskt bearbetade. Vol. IX. - Lund, 219 pp.

THomson, C. G. 1874: Bidrag till Skandinaviens Coleoptera. - Opusc. ent. (Thomson), 6: 535-553. 
WALLIS, J. B. 1939: The genus Graphoderus AuBÉ in North America (north of Mexico) (Coleoptera). - Can. Ent., 71: 128-130.

WEHNCKE, E. 1871: Drei neue europäische Hydroporus. - Berl. ent. Zeitschr., 15: 163-164.

ZarTzEV, F. A. 1915: Water beetles in the MoTschulsky collection. I. Haliplidae, Dytiscidae, Gyrinidae. Eschegodn. Zoolog. Muz. Akad. Nauk, 20: 239-295.

ZATTZEV, F. A. 1953: Nasekomye zhestkokrylye. Plavuntsovye i vertyachki. - Fauna SSSR, 58: 1-376.

ZasypKina, I. A.; Ryabukrmn, A. S.; MaKaRCHENKo, E. A. \& MAKaRCHENKo, M. A. 1996: Review of amphibic insects of northeast Asia. Russian Academy of Science, Magadan. [In Russian.]

ZIMMERMAN, J. R. \& SMTtH, R. L. 1975: The genus Rhantus (Coleoptera: Dytiscidae) in North America. Part I. General account of the species. - Trans. Am. ent. Soc., 101: 33-123.

ZIMMERMANN, A. 1922: Einige neue Dytisciden. - Notulae ent., 2: 19-21.

ZIMMERMANN, A. 1925: Entomologische Ergebnisse der schwedischen Kamtchatka-Expedition 1920-1922. 9. Haliplidae und Dytiscidae. - Arkiv för Zoologi, 18B(5): 1-3.

ZIMMERMANN, A. 1928: Neuer Beitrag zur Kenntnis der Schwimmkäfer. - Wiener ent. Zeitung, 44: 165-187. ZIMMERMANN, A. 1931: Monographie der paläarktischen Dytiscidae. II. Hydroporinae (2. Teil: Die Gattung Hydroporus CLAIRV.). - Koleopt. Rdschau, 17: 97-159.

ZIMMERMANN, A. 1933: Monographie der paläarktischen Dytisciden, IV. Hydroporinae (4. Teil). - Koleopt. Rdschau, 19: 153-193.

ZIMMRRMANN, A. 1934: Monographie der paläarktischen Dytiscidae. V. Colymbetinae (1. Teil). - Koleopt. Rdschau, 20: 138-214.

\author{
Author's addresses: \\ ANDERS N. NILSSON \\ Department of Animal Ecology \& \\ Department of Biology \\ SE-901 87 Umeå University \\ Sweden
}

\author{
NoBORU MINAKAWA \\ College of Forest Resources \\ Univ. of Washington, Seattle \\ Washington 98105 \\ USA
}

\author{
SERGEY K. KHOLNN \\ Laboratory of Entomology \\ Institute of Biology and Pedology \\ Vladivostok 22 \\ 690022 Russia
}









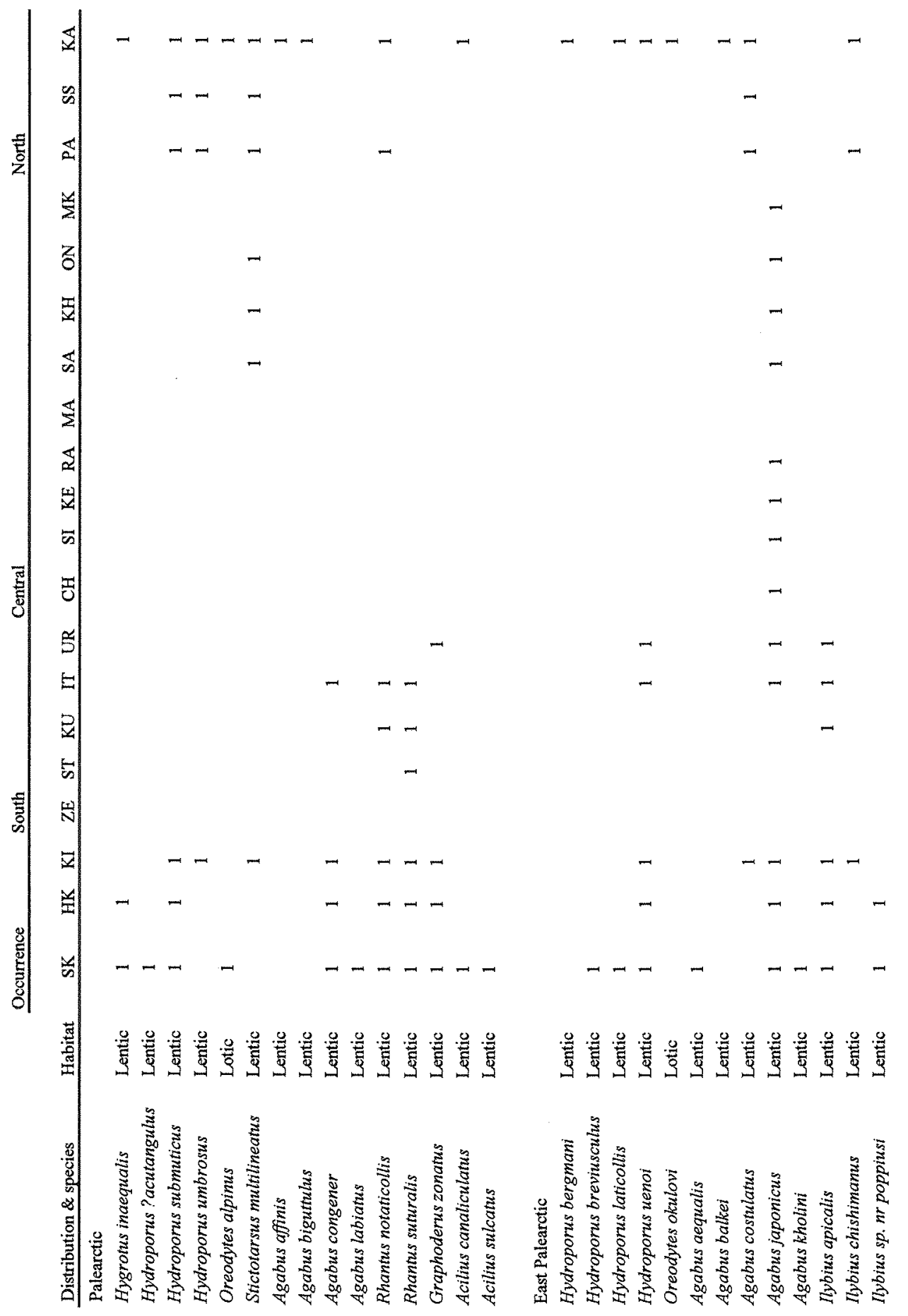




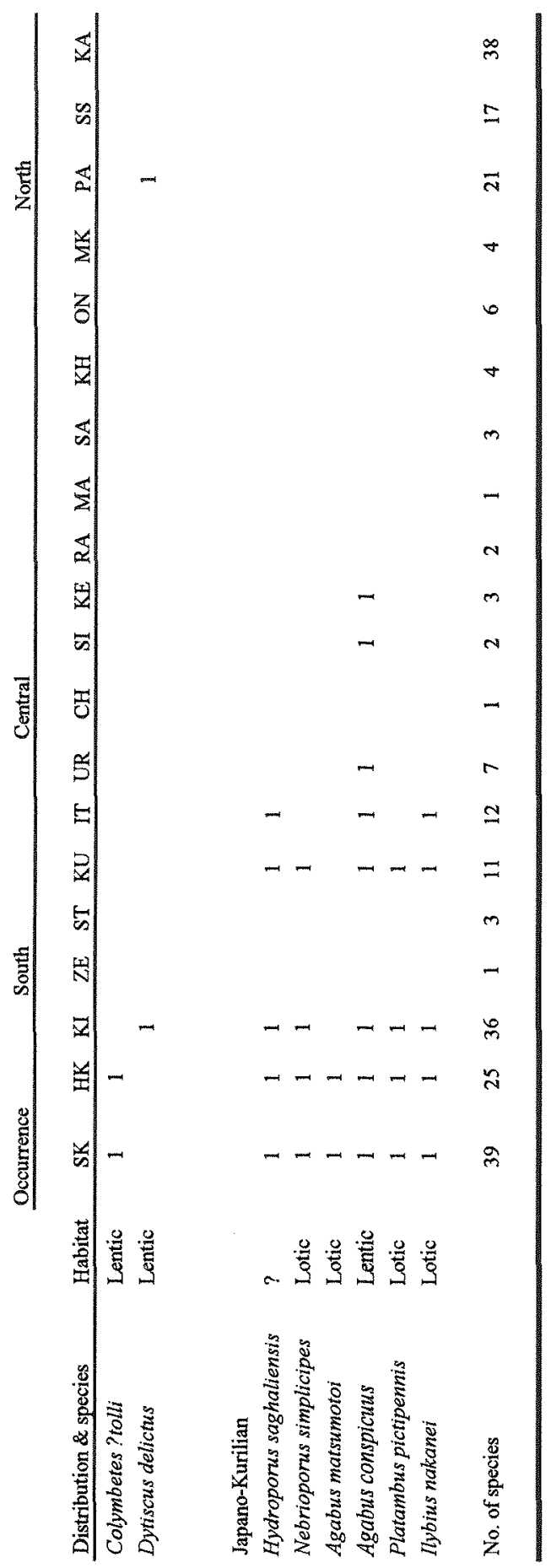




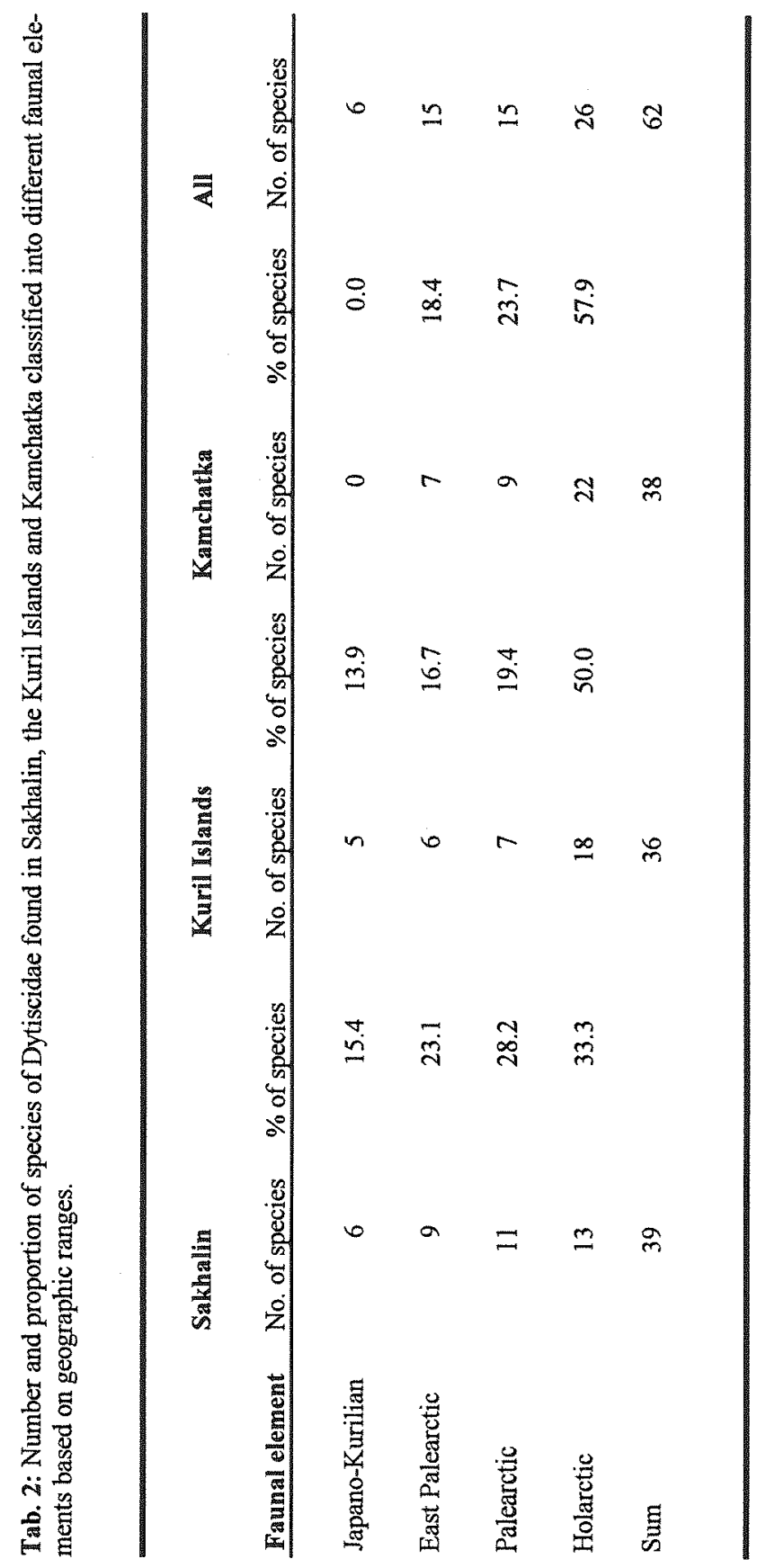

